Aim of the study: Oral mucositis is the most commonly reported side effect observed in neoplastic patients treated with chemotherapy and radiotherapy of the head and neck region as well as in patients who have received a haematopoietic stem cell transplant. The aim of the study was to assess the oral mucosa status in children with acute lymphoblastic leukaemia (ALL) during antineoplastic therapy.

Material and methods: The clinical examination included 78 children aged 2-18 with ALL. The clinical examination was conducted using the dental preset tray. The condition of the oral mucosa was determined using the WHO scale for oral mucositis.

Results: In the first period of antineoplastic therapy the pathological lesions of the oral mucosa of the mucositis type were observed among the examined patients. The lesions had various levels of intensity. Pain was found to be the primary symptom of oral mucositis. In this study the following were observed: local erythema of the oral mucosa in $35 \%$, white pseudomembranous lesions in $18 \%$, erosions in $40 \%$ and oral ulcerative lesions in $4 \%$ of patients who underwent the antineoplastic therapy. Oral mucositis was observed in $3.17 \%$ of children after 6 months of chemotherapy.

Conclusion: Local treatment of oral mucositis with polyantibiotic-antifungal mixture, supporting antifungal systemic treatment, and improving the overall peripheral blood conditions in children suffering from acute lymphoblastic leukaemia improve the condition of the oral mucosa.

Key words: oral mucositis, acute lymphoblastic leukaemia (ALL), children.

\section{Oral mucositis in children suffering from acute lymphoblastic leukaemia}

\author{
Elżbieta Pels
}

Chair and Department of Paedodontics, Medical University of Lublin, Poland

\section{Introduction}

Pathological changes of the oral mucosa defined as oral mucositis are caused by cytotoxic effects of chemotherapy and local radiotherapy of the head and neck region. Oral mucositis symptoms are also observed in 40-100\% of patients who have had stem cell transplantation. Oral inflammation caused by stomatotoxic chemotherapy is painful and restricts oral administration of drugs, also increasing the risk of infection of the intrinsic oral cavity flora. It is a serious problem, which results in decreased doses of administered drugs and may increase the cost of tumour treatment. General incidence of mucositis may differ and depends on the diagnosis and the patient's age, previous condition of the oral cavity, as well as the type, dose and frequency of administration of pharmacological medicines. WHO distinguishes five grades of oral mucositis severity: 0 - no symptoms of oral mucositis; 1 - redness, erythema, soreness; 2 - erythema and ulceration, patient can swallow solid food; 3 - ulceration and erythema, patient cannot swallow solid food; 4 - ulceration and pseudomembrane formation of such severity that alimentation is not possible. Development of oral cavity inflammation defined as mucositis is claimed to be a complex pathological process, in which proinflammatory cytokines play an essential role. In a five-phase model of mucositis pathogenesis, the primary cause and trigger of the inflammatory process, is microvascular injury to quickly dividing basal epithelial cells during radiation and chemotherapy, which results in production and release of free oxygen radicals, which in turn activates cytokines, including tumour necrosis factor-alpha, produced mainly by macrophages and interleukin-1 and -6. Developing ulcers in the mucosa are a base for development of bacterial microflora leading to secondary infections. The fifth and last phase is healing, which is characterised by epithelial cell proliferation, tissue differentiation and recovery of epithelial integrity [1-7].

Among patients treated according to the protocol for high risk patients, severe mucositis occurs in more than $60 \%$. Half of those patients experience deterioration of the oral mucosa condition, which is so serious that it requires changes in the anti-tumour treatment and/or administration of parenteral analgesia. Observations reveal that oral mucositis occurs more often in children than in adults with a similar tumour disease. Oral inflammation is also more often observed in patients after bone morrow transplantation [2, 7-13].

\section{Aim of the study}

The aim of the study was to assess oral mucosa in children suffering from acute lymphoblastic leukaemia during anti-tumour treatment.

\section{Material and methods}

The study included 78 children aged from 2 to 18 suffering from acute lymphoblastic leukaemia (ALL). In the study group, 5 children had leukaemia recurrence in the cerebrospinal fluid, 2 had recurrence in the bone marrow, 7 had their CNS affected and 3 had Down's syndrome. Children with ALL were examined in three stages: examination 1 - prior to chemotherapy; examination 
2 - after initiation of chemotherapy to five months of treatment; examination 3 - in the period from 0.5 to 1.5 year of anti-tumour treatment. The children were treated according to the ALLIC BFM 2002 programme.

All the children were ordered to regularly rinse the oral cavity with preparations of chlorhexidine (Corsodyl) or benzydamine hydrochloride (Tantum verde), as well as with a herbal mixture (Dentosept).

The stomatological clinical study was conducted by a dentist using basic diagnostic tools in artificial lightning. The clinical study was used to assess oral mucosa based on the fivegrade WHO classification of oral mucositis. Another study was conducted a few days after the initiation of chemotherapy. Changes in oral mucosa were monitored every day.

\section{Results}

Prior to anti-tumour therapy, $4.84 \%$ of children with ALL had mild oral inflammation unrelated to chemotherapy, which probably resulted from decreased immunity of the affected children.

The first symptom of oral mucositis is pain. Local redness of mucosa was observed in 35 of the study children, milky white opacity of mucosa was observed in 18\%, single erosions in $40 \%$ and massive ulcers in the mucosa in $4 \%$ of the study children.

In our own studies, lesions of the mucositis type were observed in ALL children in the period from 48 hours to 6 months, having various intensity and with periods without pathological lesions, which was related to the intensity of the chemotherapy. Mucosa opacity followed by redness usually occurred within 2-4 days from the methotrexate infusion. The most severe lesions of the oral mucosa were observed after the first month of chemotherapy. Wounds and ulcers difficult to heal were related to blood parameters. It was observed that healing was faster, especially with regard to oral mucosa ulceration, when blood morphological parameters were improved. Lesions of the mucositis type were also dependent on the level of neutropenia. Each child with neutropenia also had fungal complications in the oral mucosa. In 5 children, lesions in the oral cavity were accompanied by complications in further sections of the alimentary tract. Two children had parenteral nutrition. However, no lesion intensification was observed in relation to the ALL group risk.

In the periods between protocols, there were usually no lesions.

After 6 months of chemotherapy, lesions in oral mucosa were less intense and were observed in $3.17 \%$ of the study children. The lesions were usually redness and erosion. No ulcers in the oral cavity were observed.

When lesions appeared in the oral mucosa, children were administered a mixture for oral swabbing containing sodium bicarbonate, gentamicin, Colimycin and nystatin. When massive ulceration in the oral cavity occurred, children were administered Solcoseryl ampoules i.v. and Solcoseryl Adhesive Paste on the oral mucosa. In the case of massive milky white opacities, the treatment included antifungal preparations of the azole group, e.g. fluconazole $10 \mathrm{mg} / \mathrm{kg} /$ daily.

Inflammatory changes in the oral mucosa usually regressed after a few days up to three weeks from the implementa- tion of treatment, and were mostly dependent on blood morphology and haematological therapy, as well as on the oral cavity hygiene prior to treatment. Lesions in oral mucosa were the most persistent in children with bone marrow aplasia (up to 3 weeks) and in children with neutropenia. Difficult healing was also observed following methotrexate infusion.

\section{Discussion}

Severe type of oral mucositis may be the cause of antitumour treatment postponement or modification, which results in decreased effect of the therapy $[14,15]$.

Most frequently, changes of the mucositis type are observed 2-4 days after administration of methotrexate. Lesions usually develop on buccal and tongue mucosa, as well as on the lips. The average time of development of mucositis-like lesions and ulcers was about 10-16 days of chemotherapy. Problems in the oral cavity occurred independently of the chemotherapy protocol [16-18]. Patients with aplasia or neutropenia are especially exposed to dangerous fungal complications. Therefore, introduction of antifungal prevention in the form of $100 \mathrm{mg}$ of fluconazole daily may significantly reduce occurrence of pathological changes [19, 20]. Proper function of bone marrow and improvement in blood morphology parameters lead to regression of changes in the oral mucosa [21].

According to Karolewska et al., problems of the oral mucositis type in children with leukaemia are related to a great extent to a reduced level of S-IgA, myeloperoxidase, salivary peroxidase and to almost half the level of the total protein in saliva in comparison to patients with acute leukaemia without symptoms of oral mucositis [22, 23].

The intensity of oral inflammation significantly depends on oral hygiene, which was confirmed by McGaw et al., who observed less intense and shorter symptoms of oral mucositis in subjects using mouthwash with chlorhexidine [24]. Studies conducted by Hameralak indicate a correlation between development of oral mucositis following intensive cytostatic treatment with alkaline increase in saliva pH in children with leukaemia. Irrigation of the oral cavity during chemotherapy with solution compatible with the saliva $\mathrm{pH}$ of the child resulted in a reduced intensity of inflammatory necrotic changes [25]. The authors, who had observed poor oral hygiene in children prior to bone marrow transplantation, included the patients in routine dental care in order to minimise the occurrence of complications and infections in the oral cavity. The procedure included teaching the children to brush their teeth and to clean them with dental floss, as well as fluoride varnish [26, 27].

An important problem related to oral mucositis is pain, which leads to poor nourishment and insufficient hydration of the patients and increases the risk of local infections, especially systemic ones, which may pose a threat to life. Complications in the oral cavity may also prolong treatment and increase its cost [6, 28-31].

Among preparations able to decompose dental plaque and prevent development of a new one, chlorhexidine seems to be the most effective. Numerous authors confirm chlorhexidine efficacy in $0.1 \%$ or $0.12 \%$ solution in the treatment of oral inflammatory conditions [2, 16, 18, 24, 32]. Certain re- 
searchers, however, do not recommend chlorhexidine preparations for children, claiming that mouthwashes containing fluoride compounds or saline have comparable therapeutic effects. Especially chlorhexidine solutions $0.2 \%$ or $0.3 \%$ (Skinsept oral ${ }^{\circledR}$ ) are not recommended for children with acute lymphoblastic leukaemia, due to their flavour and tendency to discoloration. According to some researchers, both chlorhexidine and benzydamine have a positive effect on reduction of oral mucositis during chemotherapy, but only in children over 6 years of age [5, 33-35]. Significant reduction of xerostomia and pain symptoms due to oral mucositis was observed following the use of mouthwash containing saturated calcium phosphate (Caphosol) combined with fluoride preparations [36, 37].

Currently, it is recommended that prevention of oral mucositis in patients with haematological neoplasms who have undergone stem cell transplantation be based on Palifermin, a preparation containing a recombined form of keratinocyte growth factor (KGF). Following the use of Palifermin in these patients, oral mucositis grade 3 and 4 was statistically significantly reduced, and the average time of its occurrence was lower than in the control group [37]. Efficacy of the preparation was confirmed for intravenous administration, whereas local administration seems to be less effective $[5,15,34,36,39]$.

All physicians agree that the most important factor lowering the risk of oral complications is regular, at least twice a day, brushing of teeth, mouth washing and effective motivation of the patient to clean dental surfaces and oral tissues of the oral cavity. Some studies recommend that during chemotherapy, the toothbrush should be placed in a $2 \%$ chlorhexidine solution after each use, and thoroughly rinsed prior to use [8, 33-35, 39-44].

In conclusion: local treatment of oral mucositis with a polyantibiotic and antifungal mixture supported by antifungal general treatment and improvement in blood morphology in children suffering from acute lymphoblastic leukaemia improves the condition of the oral mucosa.

\section{Acknowledgement}

The author gratefully acknowledges Professor Jerzy R. Kowalczyk for the possibility of conducting the research work at the Department of Paediatric Haematology and Oncology, Medical University of Lublin, Poland.

\section{References}

1. Belfield PM, Dwyer AA. Oral complications of childhood cancer and its treatment: current best practice. Eur J Cancer 2004; 40: 1035-41.

2. Carl W. Oral complications of local and systemic cancer treatment. Curr Opin Oncol 1995; 7: 320-4.

3. Cioch M. Uszkodzenie bariery śluzówkowej (mucosal barrier injury - MBJ) W następstwie intensywnego leczenia cytostatycznego. Onkol Pol 2001; 4: 85-9.

4. Lalla RV, Sonis ST, Peterson DE. Management of Oral Mucositis in Patients Who Have Cancer. Dent Clin N Am 2008; 52: 61-77.

5. Scully C, Sonis S, Diz PD. Oral mucositis. Oral Dis 2006; 12: 229-41. 6. Sonis ST, Elting LS, Keefe D, Peterson DE, Schubert M, Hauer-Jensen M, Bekele BN, Raber-Durlacher J, Donnelly JP, Rubenstein EB; Mucositis Study Section of the Multinational Association for Supportive Care in Cancer; International Society for Oral Oncology. Perspectives on cancer therapy-induced mucosal injury: pathogenesis, measurement, epidemiology, and consequences for patients. Cancer 2004; 100 (9 Suppl.): 1995-2025.

7. Sonis ST. Mucositis as a biological process: a new hypothesis for the development of chemotherapy-induced stomatotoxicity. Oral Oncol 1998; 34: 39-43.

8. Bonnaure-Mallet M, Bunetel L, Tricot-Doleux S, Guérin J, Bergeron C, LeGall E. Oral complications during treatment of malignant diseases in childhood: effects of tooth brushing. Eur J Cancer 1998; 34: 1588-91.

9. Epstein JB, Hancock PJ, Nantel S. Oral candidiasis in hematopoietic cell transplantation patients: an outcome-based analysis. Oral Surg Oral Med Oral Pathol Oral Radiol Endod 2003; 96: 154-63.

10. Haytac MC, Dogan MC, Antmen B. The results of a preventive dental program for pediatric patients with hematologic malignancies. Oral Health Prev Dent 2004; 2: 59-65.

11. Kozak I, Dwilewicz-Trojaczek J, Karakulska-Prystupiuk E, Grzegorczyk-Jaźwińska A, Górska R. Ostra i przewlekła choroba GVHD (Graft-Versus-Host Disease) - przegląd piśmiennictwa. Czas Stomatol 2004; 57: 784-89.

12. Raber-Durlacher JE, Weijl NI, Abu Saris M, de Koning B, Zwinderman $\mathrm{AH}$, Osanto S. Oral mucositis in patients treated with chemotherapy for solid tumors: a retrospective analysis of 150 cases. Support Care Cancer 2000; 8: 366-71.

13. Sonis AL, Waber DP, Sallan S, Tarbell NJ. The oral health of long-term survivors of acute lymphoblastic lekaemia: a comparisonof three treatment modalites. Oral Oncol Eur J Cancer 1995; 31B: 250-2.

14. Olczak-Kowalczyk D, Daszkiewicz M, Adamowicz-Klepalska B, Mielnik-Błaszczak M, Dembowska-Bagińska B, Perek D. Stan uzębienia i higiena jamy ustnej $u$ dzieci po przebytej terapii przeciwnowotworowej. Ann Acad Med Gedan 2004; 34: 237-55.

15. Olczak-Kowalczyk D, Daszkiewicz M, Daszkiewicz P, Kowalczyk W, Bagińska-Dembowska B, Perek D. Wybrane problemy stomatologiczne pacjentów poddanych terapii przeciwnowotworowej na podstawie klasyfikacji CTCAE v3.0. Stomatol Współcz 2007; 14 (suppl 1): 20-7.

16. de Brito Costa EMM, Fernandes MZ, Quinderé LB, de Souza LB, Pinto LP. Evaluation of an oral preventive protocol in children with acute lymphoblastic leukemia. Pesqui Odontol Bras 2003; 17: 147-50.

17. de Oliveira Lula EC, de Oliveira Lula CE, Alves CM, Lopes FF, Pereira $A L$ Chemotherapy-induced oral complications in leukemic patients. Int J Pediatr Otorhinolaryngol 2007; 71: 1681-85.

18. Pereira Pinto L, de Souza LB, Gordón-Núñez MA, Soares RC, de Brito Costa EM, de Aquino AR, Fernandes MZ. Prevention of oral lesions in children with acute lymphoblastic leukemia. Int J Pediatr Otorhinolaryngol 2006; 70: 1847-51.

19. Nicolatou-Galitis O, Athanassiadou P, Kouloulias V, et al. Herpes simplex virus-1 (HSV-1) infection in radiation-induced oral mucositis. Support Care Cancer 2006; 14: 753-62.

20. Epstein JB, Ransier A, Lunn R, Chin E, Jacobson JJ, Le N, Reece D. Prophylaxis of candidiasis in patients with leukemia and bone marrow transplants. Oral Surg Oral Med Oral Pathol Oral Radiol Endod 1996; 81: 291-6.

21. Wiśniewska J, Tyczyńska U. Stan uzębienia dzieci chorych na ostrą białaczke limfoblastyczna. Czas Stomatol 1992; 45: 393-6.

22. Karolewska E, Kozłowski Z, Konopka T, Mendak M. Zmiany na błonie śluzowej jamy ustnej w przebiegu białaczek u dzieci - obraz kliniczny. Dent Med Probl 2004; 41: 675-81.

23. Karolewska E, Konopka T, Pupek M, Chybicka A, Mendak M. Antibacterial potential of saliva in children with leukemia. Oral Surg Oral Med Oral Pathol Oral Radiol Endod 2008; 105: 739-44.

24. McGaw WT, Belch A. Oral complications of acute leukemia: prophylactic impact of a chlorhexidine mouth rinse regimen. Oral Surg Oral Med Oral Pathol 1985; 60: 275-80.

25. Hamerlak Z, Banach J. Wyniki leczenia ciężkich zapaleń jamy ustnej u dzieci chorych na ostre białaczki i chłoniaki złośliwe. Dent Med Probl 2004; 41: 687-94.

26. Lalla RV, Peterson DE. Oral mucositis. Dent Clin N Am 2005; 49: 167-84.

27. Vaughan MD, Rowland CC, Tong X, Srivastava DK, Hale GA Rochester R, Kaste SC. Dental abnormalities in children preparing for pediatric bone marrow transplantation. Bone Marrow Transplant 2005: 36: 863-66 
28. Epstein JB, Schubert MM. Managing pain in mucositis. Semin Oncol Nurs 2004; 20: 30-7.

29. Herrstedt J. Prevention and management of mucositis in patients with cancer. Int J Antimicrob Agents 2000; 16: 161-3.

30. Karolewska E, Konopka T. Algorytm stomatologicznego postępowania profilaktyczno-leczniczego u dzieci z białaczkami. Czas Stomatol 2006; 59: 245-52.

31. Peterson DE. New strategies for oral mucositis management in cancer patients. J Support Oncol 2006; 4 (2 suppl. 1): 9-13.

32. Mielnik-Błaszczak M, Stanios-Śnieżyńska J. Zastosowanie 0,2\% glukonianu chlorheksydyny w profilaktyce próchnicy u dzieci. Mag Stomatol 2001; 11: 26-9.

33. Cheng KK, Chang AM, Yuen MP. Prevention of oral mucositis in paediatric patients treated with chemotherapy; a randomised crossover trial comparing two protocols of oral care. Eur J Cancer 2004; 40: 1208-16.

34. Harris DJ, Eilers J, Harriman A, Cashavelly BJ, Maxwell C. Putting evidence into practice: evidence-based interventions for the management of oral mucositis. Clin J Oncol Nurs 2008; 12: 141-52.

35. Pitten FA, Kiefer T, Buth C, Doelken G, Kramer A. Do cancer patients with chemotherapy-induced leukopenia benefit from an antiseptic chlorhexidine-based oral rinse? A double-blind, block-randomized, controlled study. J Hosp Infect 2003; 53: 283-91.

36. Treister N, Sonis S. Mucositis: biology and management. Curr Opin Otolaryngol Head Neck Surg 2007; 15: 123-9.

37. Papas AS, Clark RE, Martuscelli G, O'Loughlin KT, Johansen E, Miller KB. A prospective, randomized trial for the prevention of mucositis in patients undergoing hematopoietic stem cell transplantation. Bone Marrow Transplant 2003; 31: 705-12.

38. Radtke ML, Kolesar JM. Palifermin (Kepivance) for the treatment of oral mucositis in patients with hematologic malignancies requiring hematopoietic stem cell support. J Oncol Pharm Pract 2005; 11: 121-5.

39. van der Rijt CCD, van Zuijlen L. Studies on supportive care in oral mucositis: random or randomised? Eur I Cancer 2001; 37: 1971-5.

40. Cheng KK, Molassiotis A, Chang AM. An oral care protocol intervention to prevent chemotherapy-induced oral mucositis in paediatric cancer patients: a pilot study. Eur J Oncol Nurs 2002; 6: 66-73.

41. Cheng KK. Children's acceptance and tolerance of chlorhexidine and benzydamine oralrinses in the treatment of chemotherapy-induced oropharyngeal mucositis. Eur J Oncol Nurs 2004; 8: 341-9.

42. de Koning BA, Philipsen-Geerling B, Hoijer M, Hählen K, Büller HA, Pieters R. Protection against chemotherapy induced mucositis by TGFbeta(2) in childhood cancer patients: results from a randomized crossover study. Pediatr Blood Cancer 2007; 48: 532-9.

43. Keefe DM, Schubert MM, Elting LS, et al. Mucositis Study Section of the Multinational Association of Supportive Care in Cancer and the International Society for Oral Oncology: Updated clinical practice guidelines for the prevention and treatment of mucositis. Cancer 2007; 109: 820-31.

44. Konopka T, Mendrela E, Norowska M, Kozłowski Z, Chaber R, Toporski J. Zmiany w jamie ustnej w przebiegu białaczek u dzieci. Czas Stomatol 2001; 54: 217-25.

\section{Address for correspondence}

\section{Elżbieta Pels}

Katedra i Zakład Stomatologii Wieku Rozwojowego

Uniwersytet Medyczny w Lublinie

ul. Karmelicka 7

20-081 Lublin

e-mail: elzbieta.pels@umlub.pl

Submitted: $\quad 30.12 .2010$

Accepted: $\quad 2.12 .2011$ 